\title{
ВЛАСТЬ В ЭТНОПОЛИТИЧЕСКОМ КОНТЕКСТЕ
}

\section{ВЛАСТЬ И РУССКИЙ НАЦИОНАЛИЗМ В СОВРЕМЕННОЙ РОССИИ}

\author{
B.А. Ачкасов
}

DOI: https://doi.org/10.31119/pe.2018.5.7

\begin{abstract}
Аннотация. Отмечается сложность и противоречивость отночений российской власти и русского национализма. В первые годы существования независимой России многие наблюдатели предсказывали усиление политической роли русского этнического национализма. Особенно часто такие прогнозы делались после неожиданного электорального успеха партии В.В. Жириновского в декабре 1993 г. Однако этот прогноз тогда не подтвердился. В новом столетии доминирующее положение в рамках русского национализма заняли имперско-великодержавные и этнонационалистические идеи и силь. После выбора, сделанного российской властью в пользу евразийского интеграционного проекта, предполагалось, что русскому национализму можно предложить в качестве основы для сотрудничества евразийскую «цивилизационную» идентичность и традиционное антизападничество. На протяжении ряда лет проводилась работа по рекрутированию, кооптации и «приручению» лидеров ряда националистических организаций (официильные должности для некоторых деятелей этого лагеря, селективный доступ в государственные СМИ, финансовая поддержка некоторых начионалистических интернет-сайтов и др.). Однако в своем стремлении «приручить» этнический русский национализм власти столкнулись с рядом серьезных препятствий. Поэтому в 2010-2011 г2. российская власть обратилась к борьбе против радикальных националистических
\end{abstract}


групп. Однако поскольку государственная идентификащия («россиянин», «гражданин России») в каком-то смысле есть инобытие русской этнической идентичности, постольку у этнического русского национализма есть политическое будущее.

Ключевые слова: имперский и этнический русский национализм, этническая идентичность, российская власть, евразийская идея, цивилизационная идентичность.

Практически неизбежное повышение значимости этнической идентичности в кризисных условиях отмечают многие исследователи. Это связано прежде всего с тем, что большинство людей, утрачивая идентификацию с прежними разрушенными социальными структурами и ценностями, не теряют этническую идентичность, приобретающую именно поэтому гипертрофированное значение для членов переживающего глубокий кризис социума. Именно в такой ситуации происходит «возврат к этничности», актуализация ранее не востребованной, находящейся в латентном состоянии этнической идентичности.

Это подтверждается и данными социологических исследований. Так, если в 1989 г., по данным опроса ВЦИОМ, удельный вес самохарактеристики «Я - советский человек» (которая была одной из самых значимых) среди русских в России составлял 30 \%, а среди жителей столиц - 38 \% [Советский простой человек... 1993: 131], то уже в первой половине 1990-х годов, по данным исследования под руководством Л.М. Дробижевой, ее место в групповых «Я-образах» было занято именно этнической принадлежностью: «В целом по представленности она четвертая, после семейной, профессиональной и половой принадлежности в групповых “Я-образах" татар, осетин, саха и русских в Саха (Якутии) и Северной Осетии (Алании)» [Дробижева, Аклаев, Коротеева, Содатова 1996: 306] ${ }^{1}$.

Неслучайно поэтому в первые годы существования независимой демократической России многие наблюдатели предсказывали

${ }^{1}$ Исследование проводилось в республиках Татарстан, Саха (Якутия), Северная Осетия (Алания) и Тыва. 
резкое усиление политической роли этнического национализма, прежде всего радикального русского национализма. Особенно часто такие прогнозы делались после неожиданного электорального успеха партии В.В. Жириновского в декабре 1993 г. Так, западный эксперт писал тогда: «Большое число голосов, поданных за националистическую партию Владимира Жириновского, продемонстрировало явную угрозу и без того хрупким институтам российской демократии и вызвало у соседей России страх за собственную безопасность» [Готтлиб 1995: 21-35; Янов 1995; Умланд 2001: 71-84; 2006: 221-262]. Активно обсуждалась эта проблема и внутри нашего Отечества [Нужен ли Гитлер России... 1996; Мигранян 1997 и др.].

Однако этот прогноз в отношении русского национализма не подтвердился. Из множества возникших в этот период националистических партий некоторого успеха на федеральном уровне добивалась Национал-республиканская партия России (НРПР), лидер которой, Н. Лысенко, некоторое время даже был депутатом Государственной Думы. К сколько-нибудь значимым русским национально-патриотическим силам середины 1990-х годов В. Прибыловский относил Российский общенародный союз (РОС) Сергея Бабурина, «Державу» Александра Руцкого, Русский национальный собор (РНС) Александра Стерлигова, вторую Национально-республиканскую партию (Юрия Беляева, помимо партии Николая Лысенко), Русское национальное единство (РНЕ) Александра Баркашова [Прибыловский 1996: 17]. Однако все они оставались политическими маргиналами.

Валерий и Татьяна Соловей связывают скромный политический успех русских националистов с их неподготовленностью к новым реалиям постсоветской России. В частности, они выделяют три фактора, об этом свидетельствовавшие: «во-первых, неадекватность националистических программ и лозунгов социокультурному и политико-идеологическому профилю российского общества. Антидемократическая, антирыночная и антисемитская идеология в сочетании с публичной лояльностью коммунистическому режиму подорвали возможности русской националистической мобилизации <...>; во-вторых, интеллектуальная и культур- 
ная ригидность националистов усугублялась дефицитом волевых качеств, экзистенциальной трусостью и почти хрестоматийной русской ленью <...>; в-третьих, слабость русских национальных чувств, разрушенных и подорванных коммунистической национальной стратегией, ограничивала возможности “чистой” националистической мобилизации» [Соловей, Соловей 2011: 352].

Все попытки националистов объединиться, консолидировать позицию также оказались на редкость безуспешными. «Взаимная неприязнь националистов друг к другу превосходила их ненависть к ельцинскому режиму... Они нередко выступали в роли охвостья вновь созданной коммунистической партии. Левые ценности оказались в России национальной традицией - более живучей и влиятельной, чем русская националистическая традиция», - считают В. и Т. Соловей. Они же констатируют: «В 1990-е гг. ключевыми игроками на националистическом поле стали две партии: националистическая, но оппортунистическая ЛДПР и оппозиционная, но не националистическая, а левоконсервативная КПРФ. Многие голосовавшие за Зюганова и Жириновского не испытывали к ним симпатии, но не желали, чтобы пропали их голоса» [Соловей, Соловей 2011: 355, 367, 34].

Таким образом, можно констатировать, что «хотя русский национализм так и не превратился в самостоятельного игрока, в субъекта российской политики, само его существование, изрядно раздутое и мифологизированное СМИ (особенно западными, например можно вспомнить постоянные алармистские прогнозы подъема русского фашизма в 1990-е и даже 2000-е гг. - В.А. $)^{2}$, влияло на общенациональную повестку и легитимировало русскую этническую проблематику. Массированная медийная критика

${ }^{2}$ Свою роль в этой кампании сыграли и европейские институты. Так, в 2006 г. проблема российского национализма стала предметом резолюции Парламентской ассамблеи Совета Европы [ПАСЕ призвала... 2006]. Позднее доклад о росте национализма, ксенофобии и расизма в России в 2008-2012 гг. стал темой обсуждения Европейской комиссии по борьбе с расизмом и нетерпимость - специального органа Совета Европы, учрежденного для мониторинга в этой сфере [В Совете Европы... 2013]. 
(русского) национализма буквально впаяла его в массовое сознание. Кремль и оппоненты национализма сделали для индоктринации его идей несравненно больше националистов» [Соловей, Соловей 2011: 405-406]. Тем не менее к концу 1990-х годов «уже не только слово “патриот", но и нелепое словосочетание “националпатриот” перестают быть пугающими и ругательными даже для большинства “демократов”, и тема патриотизма как естественной непридуманной национальной идеи начинает звучать все громче» [Салмин 2007: 7] $]^{3}$.

Как справедливо отмечает политолог Марлен Ларюэль, «национализм (русский - B.A.) полифоничен...: есть национализм проигравших в результате постсоветских реформ, который выражается в протестном голосовании за КПРФ или за ЛДПР В. Жириновского (на парламентских выборах и за Г. Зюганова, и за генерала А. Лебедя на президентских выборах в 1990-е гг. - B.А.); есть государственный (консервативный) национализм политических элит, которые поддержали патриотический призыв “Единой России”, объединяющий ностальгию по Советскому Союзу и постсоветские реалии; есть этнический национализм малообразованных и малообеспеченных слоев молодежи, который выражает себя в актах насилия скинхедов; и наконец, национализм городского среднего класса (который, кстати, появился на сцене последним, по характеру проевропейский и демократический, но при этом ксенофобский), выразителями которого стали национал-демократы и А. Навальный» [Ларюэль 2014: 59].

Однако в новом столетии доминирующее положение в рамках русского национализма заняли имперско-великодержавные и этнонационалистические («русистские») идеи и силы. Один из заметных представителей имперского направления в русском национа-

3 По мнению С.В. Лебедева, эта «кличка» (национал-патриот) изначально была оскорбительной, направленной на создание ассоциации с понятием «национал-социализм», воспринимающимся в массовом сознании негативно. Тем не менее в действительности ярлык превратился в почетное наименование, получившее широкое распространение [Лебедев 1999: 19]. 
листическом движении Д. Володихин считает, что рубеж между двумя направлениями проходит «не в сфере теоретических споров, а в плане методов борьбы»: «кровник», как правило, убежден в неизбежности новой смуты или, вернее, в ее необходимости и «исповедует радикализм по отношению к существующей власти». «Имперец» чаще напирает на необходимость «раскола» существующей элиты, работы с ее «здоровым» элементом, выступает за «мирное “продавливание”» важных преобразований во власть, указывает на «издержки вооруженной борьбы», когда любой из ее вариантов будет иметь своими итогами смерти миллионов «тех же самых русских и опять приведут к непредсказуемому результату» [Володихин 2008: 66-67] ${ }^{4}$.

Во всех вариантах имперского национализма речь идет, вопервых, о том, что империя - это многосоставное государство, поэтому Россия по определению должна оставаться империей, в противном случае она вынуждена будет лишиться значительной части своей территории. Признавая, что Россия является многонациональной страной, большинство имперских националистов особо подчеркивают главенствующую роль русского народа. Так, лидер Евразийского союза молодежи В. Коровин, всячески подчеркивая особые географические и исторические условия, в которых сформировалось и существует современное российское государство и особую роль русских в его создании и существовании, также ут-

${ }^{4}$ Классическим примером имперской националистической организации является существующий с начала 1990-х годов «Русский общенародный союз» С. Бабурина, в программе которого Россия называется «фактически и по праву» государством русских, но русских не столько по крови, то есть великороссов, сколько по культуре: мировоззрению, языку, традициям, образу жизни и т.д. Характерно, что в программе упоминается тезис о триединстве русского народа - русских, украинцев, белорусов. Народы исторической России - татары, башкиры, балкарцы и многие другие называются «братскими» и «породненными» по отношению к русским. Православие признается основой духовно-нравственной жизни страны и народа, фундаментальным принципом русского общества - социальная справедливость, а императивом русской истории - великодержавность [Программа партии... 2012]. 
верждает, что, допуская этнокультурное многообразие, евразийство не поощряет «смешения народов» [Коровин 2016].

Во-вторых, это признание универсальной объединяющей идеи, некоего глобального проекта. Потребность в общей нематериальной цели, стремление к осмысленности своего существования объявляются свойствами русского народа.

В-третьих, империя здесь - это автократический способ организации территорий и общества сверху. Приветствуется идея сильной власти [Малинова 2008: 66-79].

Кроме того, следует отметить следующие особенности современной русской великодержавной идеологии: «Все имперские проекты русских националистов в большей или меньшей степени имеют антизападную направленность, но к этому аргументу прибегают и те, кто использует темы самобытности России по отношению к Западу и в других сегментах российского публичного дискурса. В этих конструкциях есть и различия, например, в определении миссии России часть идеологов говорит о воссоздании православной империи, другие рассуждают в логике современных геополитических оппозиций и выдвигают цель восстановления евразийского единства и/или противостояния гегемонии США» [Малинова 2008: 66-79]. И те, и другие видят Россию в роли великой державы, но по-разному представляют себе территориальные границы новой империи. Однако чаще всего речь идет о восстановлении СССР в полном или усеченном варианте.

Поэтому представляется особенно интересной идейная трансформация русского государственнического/имперского национализма и изменение его отношений с российской властью, которые крайне показательны: «Распад СССР стал для многих “державников” и “руссистов” страшной экзистенциальной катастрофой, повлекшей за собой кардинальную “смену вех”. < .. > Бывшие ниспровергатели коллективизации и “красного террора" внезапно обернулись пламенными сталинскими соколами. Советская империя обрела непререкаемый статус потерянного рая, а социализм вековечного русского идеала, прямиком вытекающего из православной соборности и крестьянской общины» [Сергеев 2008: 66]. Вновь популярным стало утверждение (которое первыми сделали 
авторы «Смены вех», а ныне его приняли российские коммунисты и русские националисты-державники), что большевики просто эксплуатировали лозунг «мировой революции» ради решения «имперской задачи» - восстановления распавшейся Российской имперской государственности.

В конце концов, в качестве нового интеллектуально-идеологического основания мейстримного течения в рамках русского имперского национализма было предложено неоевразийство ${ }^{5}$. Все его теоретические интерпретации включали ряд общих принципиальных черт: требование восстановления империи, принципиально надэтнический патриотизм, однако подчеркивание особой роли русского народа, радикальное антизападничество, попытку синтеза советского и досоветского начал, интерес к геополитике. «Евразийство стало идейным синтезом, логично и непротиворечиво сочетающим в себе левые - коммунистические и советские - и правые - националистические, имперские - тенденции, которые составляли два основных вектора оппозиционной антилиберальной и антиреформаторской политики» [Кловер 2017: 325].

Евразийство, в толковании «последнего евразийца» Л.Н. Гумилева, органично продолжало линию традиционного русского имперского национализма: «не отрицало русскость как таковую, но растворяла ее в некоем сверхнациональном единстве (российском суперэтносе. - B.A.), доказывая, что сверхнациональность и есть главная, сущностная черта «русскости». Так, С.В. Кортунов (впрочем, как и многие другие авторы, заимствующие идеи Л.Н. Гумилева) пишет: «Взаимная открытость русских и тянущихся в Россию инородцев, подвижников самых разных культур и религий, привела к созданию на огромной евразийской территории единой этнической общности - российского суперэтноса. Оказавшись центром этнического и культурного притяжения не только славян, но и других сопредельных народов, русский народ был в большей сте-

5 Справедливости ради нужно отметить, что впервые евразийская идея всплывает еще в конце 1980-х годов в либеральном окружении М.С. Горбачева в форме идеи превращения реформированного СССР в мост между Европой и Азией. 
пени “российским”, чем “русским”, и в силу этого никогда не был “нацией” в западном смысле слова» [Кортунов 2009: 12]. В результате мы получаем любопытный пример «схождения крайностей»: воинствующий антикоммунист С.В. Кортунов пишет практически то же, что и пламенный коммунист - лидер КПРФ Г.А. Зюганов. Неслучайно Т. и В. Соловей приходят к заключению: «Можно назвать (новое. - B.A.) евразийство национал-большевизмом эпохи крушения коммунизма». Они же называют основных идеологов современного евразийства: А. Дугин, А. Проханов, С. Кара-Мурза, С. Кургинян [Соловей, Соловей 2011: 389].

Однако, как представляется, нужно разграничивать национализм как массовое настроение общества (так называемый «банальный национализм». - M. Биллиг) ${ }^{6}$, и национализм как притязающее на участие в политике и власти идеологическое, институализированное течение. Характеризуя национализм первого типа, социологи «Левада-центра» писали: «За исключением очень краткого момента лета - осени 1991-го, когда он, казалось, слился с демократическим движением, русский национализм всегда был только консервативным, защитным, компенсаторным и изоляционистским комплексом представлений» [Есть ли перспектива у русского национализма 2006: 263-298]. Поэтому можно отметить, что евразийское идеологическое предложение в целом шло тогда в разрез с эволюцией массового русского самосознания, как и «уличного» русского этнического национализма рубежа веков. Естественная ностальгия по сильному Советскому Союзу была ошибочно воспринята за массовые проимперские настроения россиян.

${ }^{6}$ М. Биллиг, в частности, пишет: «Банальный национализм оперирует прозаичными, обыденными словами, благодаря которым нации начинают казаться само собой разумеющимися. Короткие слова, а не громкие и пафосные фразы постоянно, но редко осознанно напоминают о Родине, не позволяя забыть о “нашей” национальной идентичности». Таким образом, «нация лежит на поверхности современной жизни» и своим актуальным существованием национализм обязан практике постоянных «естественных взаимодействий с теми, которые считаются “нашими”, “своими”, в отличие от “чужих”, “других”». [Биллиг 2007: 34]. 
В книге «Русское евразийство: идеология империи» (2008) Марлен Ларюэль справедливо отмечает, что в действительности все современные проекты неоевразийцев не имеют никакого отношения к реальному социально-политическому и экономическому состоянию региона, не учитывают постсоветский этап и игнорируют наличие в регионе таких крупных игроков, как Китай и США [Laruelle 2008: 37].

«Слабость нового евразийства в том, что оно так и не сумело добиться широкого признания. Речь идет лишь об отдельных элитарных кружках - совершенно так же, как это было в 20-х и 30-х годах. Для русских националистов евразийская идея чересчур абстрактна, то же можно сказать и о большинстве интеллигентов в исламских республиках бывшего СССР» [Люкс 2016: 155].

Из ошибочной предпосылки вырастала пагубная политическая стратегия националистов: «Курс имперской реставрации (или строительства новой евразийской империи). Эта идеология по определению не обладала (тогда) мобилизационным воздействием, ибо масса русских не желала хоть чем-то пожертвовать ради восстановления имперского монстра. Они были не прочь, если бы Советский Союз восстановился, но как-нибудь так - не больно, без напряжения, а лучше вообще без их участия» [Соловей, Соловей 2011: 392]. Это доминирующее настроение выразил Президент РФ В.В. Путин почти афористичной фразой: «Кто не жалеет о распаде Советского Союза, у того нет сердца, но у тех, кто желает его восстановления, нет разума» (цит. по: [Соловей, Соловей 2011: 393]).

Однако позже, когда Россия превратилась в «великую энергетическую державу», российский национальный лидер отошел от этой позиции. Приняв некоторые идеи современных имперцев-евразийцев и поддержав давний призыв Президента Республики Казахстан Нурсултана Назарбаева к евразийской интеграции, он явно стремится войти в историю как реинтегратор постсоветского пространства и создатель нового мирового центра силы. Неслучайно в «нулевые годы» российская власть стала активно перехватывать идеи и идеологические конструкты русского имперского национализма. Так, «Единая Россия» в 2007 г. запустила свой «Русский проект», в рамках которого стали использоваться понятия, 
заимствованные у русских националистов-имперцев: «государствообразующий народ», «этническое ядро» и др. То есть произошло проникновение в официальный дискурс этнических мотивов, причем через обсуждение места и роли русского народа. Другой пример - так называемая «Русская доктрина», которая по утверждению Э. Паина, «разрабатывалась для несостоявшейся партии Д. Рогозина “Великая Россия”, но затем была подхвачена партией власти “Единой Россией” и активно пропагандировалась ее молодежным крылом - “Молодой гвардией” [Паин 2009: 47]. Между тем «доктрина» открыто позиционирует себя как политтехнологический проект и программу прихода к власти так называемых «национал-консервативных сил». Самую широкую поддержку ей оказывает и руководство РПЦ. Паин особо отмечает, что «Русская доктрина», провозглашающая в качестве некоей системы координат для современного российского общества «особую российскую цивилизацию», по сути, является «стандартной этнонационалистической программой, обосновывающей доминирующие права одного народа и одной религии в политической системе государства» [Паин 2009: 49]. Таким образом, российская власть в нулевые годы все чаще использует националистический дискурс в качестве средства своей легитимации и, по словам одного из идеологов русского этнического национализма Константина Крылова, пытается осуществить «госприватизацию патриотических чувств».

Как уже отмечалось, идея евразийства вернулась в реальное политическое пространство с подачи казахской стороны: 29 марта 1994 г. на встрече с профессорско-преподавательским составом и студентами МГУ Президент Казахстана Нурсултан Назарбаев впервые сформулировал идею Евразийского союза [Назарбаев 2004: 110-122]. Однако окончательный переход к практической реализации «евразийского проекта» произошел в начале второго десятилетия нового века. В октябре 2011 г. в газете «Известия» была опубликована предвыборная статья В.В. Путина «Новый интеграционный проект для Евразии - будущее, которое рождается сегодня», где был предложен проект для стран СНГ, по объединению их экономических потенциалов путем создания таможенного союза, зоны свободной торговли и, возможно, единой валюты в рамках 
Евразийского союза. Суть проекта выражена следующими словами: «Мы предлагаем модель мощного наднационального объединения, способного стать одним из полюсов современного мира и при этом играть роль эффективной “связки” между Европой и динамичным Азиатско-Тихоокеанским регионом» [Путин 2011]. А в 2013 г. на заседании «Валдайского клуба» он уже заявлял: «...наш абсолютный приоритет - это тесная интеграция с соседями... Евразийская интеграция - это шанс для всего постсоветского пространства стать самостоятельным центром глобального развития, а не периферией для Европы или для Азии» [Валдайский международный... 2013]. Таким образом, евразийская интеграция стала стратегической целью и своего рода национальной идеей, предлагаемой обществу российской властью, а евразийство в его цивилизационной форме - идеологией, обосновывающей необходимость достижения этой цели. Однако в концептуальном плане образование ЕАЭС стало еще одной болевой точкой в идейно-политическом дискурсе России о выборе пути развития. Для одних - это позитивный сигнал, знаменующий собой выбор самостоятельного пути развития страны, основанного на национальной специфике. Для других шаг назад от развитой западной цивилизации, очередная утопия, в которой Россия видится уникальной страной с особым укладом [Энтин, Энтина 2016].

В то же время, по мнению американского автора Ч. Кловера: «Оппозиционные группы (русских. - B.A.) националистов воспринимались (властью. - B.A.) как смертельная угроза режиму и вместе с тем, парадоксально, и как новая политическая сила, которая может оказаться чрезвычайно полезной, если ею пользоваться должным образом <...> В евразийстве власть увидела возможность перехватить мобилизационный потенциал (русского. - B.A.) национализма, не возбудив при этом этнической розни и сепаратизма <...> Националистам, этой растущей политической силе, была предложена “мускулистая" версия евразийства и надэтнической русской цивилизации как альтернатива этническому расизму» [Кловер 2017: 408, 412]. Таким образом, предполагалось, что неконтролируемому русскому этническому ультранационализму можно предложить в качестве идейной альтернативы евразийскую «циви- 
лизационную» идентичность и традиционное для России антизападничество. Поэтому на протяжении 2005-2010 гг. под контролем Владислава Суркова проводилась работа по рекрутированию, кооптации и «приручению» лидеров ряда русских националистических организаций (официальные должности для некоторых известных деятелей националистического лагеря (Д. Рогозин), селективный доступ в государственные СМИ (А. Дугин, С. Кургинян, А. Проханов), финансовая поддержка номинально националистических интернет-сайтов и др.). В свою очередь, Т. и В. Соловей утверждают: «Можно говорить об инструментальном использовании современной российской властью националистического ресурса», то есть «дозированном обогащении официального дискурса националистической риторикой с целью мобилизовать русские этнические чувства для поддержки и укрепления власти». По их мнению, в этой ситуации «националисты совершили переход от оппозиционности к оппортунизму и даже сервильности», поскольку для них «Путин стал таким же “президентом надежды", как и для всего российского общества» [Соловей, Соловей 2010: 51].

Однако, по мнению других исследователей, от «партнерства» властей и националистов выигрывали больше правые. Они получали доступ к финансированию, устанавливали связи с политическим истеблишментом, что позволяло им «лоббировать собственные интересы на разных уровнях и формировать у общества и, что немаловажно, у автономных экстремистских групп - имидж влиятельности и возможностей неправовой, через личные связи, защиты своих сторонников». Выяснилось также, что ряд проправительственных молодежных организаций («Наши», «Молодая гвардия» Единой России», «Местные») имеют тесные связи с русскими ультраправыми, что проявляется по трем направлениям: вопервых, так называемое «кроссчленство», когда активисты ультраправых или даже целые группы числятся одновременно в рядах прокремлевских молодежных объединений; во-вторых, перехват прокремлевской молодежью ксенофобских лозунгов и практик ультраправых русских националистов; в-третьих, прямое взаимодействие с ультраправыми группировками (см.: [Кожевникова 
2010: 4-17]). В результате, казалось бы, возникали благоприятные условия для расширения социальной опоры для правых националистов по стране в целом.

Однако сформулированный выше вывод справедлив преимущественно в отношении представителей имперского русского национализма. Осуществление стратегии «управляемого национализма» касательно русских этнонационалистов сорвалось. В своем стремлении «приручить» этнический русский национализм власти столкнулись с рядом серьезных препятствий. Так, русских этнических националистов не устраивала сформулированная властью цель - построение российской гражданской нации. Результатом ее реализации, по их мнению, будет «обезличивание русского народа». Поэтому она воспринимается как попытка вновь отнять у русских национальную идентичность и подменить ее идентичностью «российской». Эта попытка, по словам одного из идейных лидеров русских националистов А.Н. Севастьянова, «воспринимается как угроза и как оскорбление национального чувства. Русские не "россияне”, “россияне” - это нерусские жители России: так понимает дело нормальный русский человек» [Севастьянов 2016: 11]. Не устраивал русских этнических националистов и евразийский интеграционный проект. Всем сторонникам евразийского проекта, по словам того же автора, «со всеми их патриотическими декларациями на деле идеалы интернационала куда ближе, чем идеалы национализма, в особенности этнического, который я считаю единственно истинным» [Там же: 15].

Росту оппозиционности русских этнических националистов способствовал и постоянно увеличивающийся и практически неконтролируемый государством приток иммигрантов из стран постсоветского пространства. Крупнейшая из правых националистических организаций «нулевых» годов «Движение против нелегальной иммиграции» (ДПНИ 2002-2011 гг.) в действительности боролась против любой иноэтнической иммиграции (за исключением восточных славян). Новым «соратникам», вступающим в ДПНИ, объясняли, что буква «Н» в аббревиатуре ДПНИ означает не нелегальную, а неславянскую иммиграцию.

Поэтому выбор российской власти в пользу евразийской инте- 
грации и сохранения открытых для миграции из стран постсоветского пространства границ (прежде всего из государств - членов ЕвразЭС) окончательно развел ее с русскими этническими националистами. Критикуя «антирусскую диктатуру В. Путина» лидер «Народной национальной партии России» А. Иванов-Сухаревский объяснял свою позицию тремя причинами: первая - поддержка этнически неполноценных олигархов; вторая - свертывание демократических свобод, поскольку в связи с изменением избирательной системы русские националисты лишены возможности легально прийти во власть и вынуждены прибегать к радикальным средствам; третья - официальное попустительство мигрантам [Кузьмин 2011: 63-64]. Действительно, «все более явная этносоциальная стратификация населения, монополизация отдельных сфер деятельности (в особенности в сфере мелкооптовой и розничной торговли, посреднической деятельности) представителями определенных этнических групп (чаще всего выходцами с Кавказа и из Центральной и Юго-Восточной Азии)... этническая окрашенность ряда структурных элементов ситуации (рэкет, наркоторговля, захват заложников и др.) провоцируют нарастание русского национализма и на бытовом уровне» [Филиппов 2001: 188].

Эту ситуацию по-своему интерпретируют русские этнические националисты. Президент Русского общественного движения К. Крылов заявляет: «Это похоже на сознательный план низведения русских до одного из нацменьшинств в собственной стране. И такое может произойти еще до середины века. Идет замена населения: на смену людям европейской культуры, знающим о правах человека, приходят носители классического, если не сказать средневекового азиатского менталитета» [Нас снесет потоком... 2012: 7]. Именно учет сильных антимигрантских настроений в российском обществе в сочетании с активной и радикальной по форме антииммигрантской пропагандой сделали ДПНИ в «нулевые» годы ведущим игроком в крайне правом националистическом лагере $\mathrm{p}^{7}$

7 Правда в экспертной среде существует мнение, что ДПНИ было создано властями для того, чтобы приручить практически неуправляемых скинхедов, так как их численный рост и агрессивность внушали резонные 
Поэтому с 2010-2011 гг. российская власть обратилась к борьбе против радикальных националистических групп, загоняя их тем самым в ряды «непримиримой оппозиции». Побудительным мотивом к этому, видимо, послужили акции футбольных фанатов в Москве и Санкт-Петербурге в декабре 2010 г., которые, как известно, переросли в массовые беспорядки под открыто ксенофобскими лозунгами и захватили ряд других крупных городов страны. Внимательный западный наблюдатель отмечал в связи с этим: «На Манежной площади собрались сотни и тысячи протестующих, среди которых многие ощущают себя жертвами маргинализации и относительной обездоленности, поскольку экономическое процветание, столь явно бросающееся в глаза в столице, для них остается недоступным. Они яростно выдвинулись в общественное пространство, заявляя свое право на долю в общественном достоянии. Власти их полностью игнорировали» [Грин 2011: 5].

В свою очередь, отечественные исследователи указывали на следующие особенности этих выступлений: «Во-первых, наличие массовой социальной организации (фанатские клубы, сетевая структура объединений футбольных болельщиков), которая, как оказалось, может быть использована для самых разных целей лидерами и организаторами таких движений <...> Во-вторых, эти акции имеют антигосударственную направленность. Взрыв эмоций был вызван именно неверием в возможность добиться справедливости в рамках закона, представлением о том, что органы правопорядка и судебная власть куплены, то есть что в стране нет правосудия <...> Адресатом массовых выступлений (в Москве в декабре 2010 года) были высшие власти страны, не выполнившие свои прямые обязанности. <...> Третье обстоятельство: консолидация стала возможной только на почве ксенофобии..., посредством негативной солидарности <..> Объединяло всех чувство ненависти к чужим, другим, архаическое единение “своих" против “чужих"»

опасения. Такая же схема, возможно, работала в целях нейтрализации Национал-большевистской партии, против которой действовал кремлевский спойлер - «Евразийский союз молодежи» А. Дугина (см.: [Кузьмин 2011: 187-188] и др.). 
[Гудков 2011: 37]. Таким образом, ксенофобия стала основой формирования мировоззрения для значительной части неустроенных, переживающих чувство относительной депривации молодых людей. Однако этот протест имел спорадический характер и не обрел своих лидеров и объединяющей позитивной цели. «Массовые националистические настроения в русском обществе (банальный национализм) и политический русский национализм не соединились, приведя к возникновению мощного политического движения» [Соловей, Соловей 2010: 51-62]. Однако этнические фобии обладают высокой инерционной устойчивостью и могут долго удерживаться в массовом сознании.

Видимо, правы те социологи, которые увязывают рост этно- и мигрантофобий в период «травматической трансформации» (П. Штомпка) с разрастающимся комплексом социальных обид, принимающих тем не менее форму не социального, а этнически или расово окрашенного протеста, не имеющего «ясного адреса». Такое объяснение прежде всего применимо к той части молодежи крупных городов из «спальных районов», которая фактически не имеет перспектив вырваться из полумаргинального, люмпен-пролетарского существования, выбраться из подвалов, получить достойное образование и сделать карьеру в нынешнем российском обществе, где социальное расслоение исключительно высоко [Мукомель 2005: 61-71]. Все сказанное подтверждает адвокат С. Беликов, озвучивший настроения, распространенные среди российских скинхедов: «У нас в России огромное количество молодых людей, не вошедших в число тех, кто преуспевает, с ужасом осознает, что они обречены на прозябание, никому не нужны, что они будут жить гораздо хуже родителей. Они понимают, что неопределенность ситуации будет длиться еще неизвестно сколько, а значит, перед ними нет будущего» [Беликов 2002: 55].

Именно 16-17-летние подростки, входящие в эту «группу риска», особенно предрасположены к восприятию обвинений во всех своих бедах «чужих»: «черных», «кавказцев», «китайцев» и др. Именно они становятся «политической пехотой» экстремистских националистических организаций и движений, именно их натравливают на этнически и расово чуждых, именно они совершают 
большую часть преступлений против иностранцев.

Поэтому власти были явно встревожены этим стихийным всплеском молодежного протеста и появлением антиимперских, антисоветских и антипутинских установок в риторике лидеров ряда националистических организаций (что некоторые эксперты поспешили назвать национал-демократической тенденцией в русском национализме) и пошли на упреждающие меры. В результате наиболее известные русские националистические организации (Движение против нелегальной иммиграции (ДПНИ) - лидер Александр Белов-Поткин ${ }^{8}$, «Славянский союз» - Дмитрий Демушкин, Национал-социалистическое общество - Дмитрий Румянцев, Национально-державная партия России (НДПР) - Александр Севастьянов) и другие были запрещены, многие русские националисты были осуждены за разжигание межнациональной розни.

Российская власть также крайне серьезно отнеслась к событиям украинского Евромайдана, особенно к развернутой во время и после этого радикальной антирусской националистической пропаганде. Среди мер, принятых в РФ, можно назвать значительное

8 Однако политическая активность самого А. Белова продолжалась. В 2011 г. вместе с еще одним представителем радикальных националистов, Д. Демушкиным он создает политическое движение «Русские», выступавшее за создание в России национального государства и правительства. Известно, что во время протестов 2011-2012 гг. «Русские» участвовали в протестных акциях по итогам выборов в Государственную Думу в 2011 г. Целый ряд союзников движения, в той или иной степени разделявших взгляды его создателей, даже вошел в Координационный совет российской оппозиции. В частности, речь идет о стороннике идей национал-демократии К. Крылове, основателе Русского общенационального союза И. Артемове, одном из организаторов «Русских маршей» В. Торе. Как отмечает М. Ларюэль, в протестный период начала 2010-х годов не только националисты приходят к сотрудничеству с демократически ориентированной оппозицией, но и некоторые демократические оппозиционеры берут на вооружение националистические лозунги. Примерами тому служат национал-демократические движения и А. Навальный, чье место в среде националистов западным исследователям было не так просто определить [Ларюэль 2014: 58]. 
расширение федерального списка экстремистских организаций. Характерным моментом является то, что наряду с русскими националистическими организациями туда были внесены целый ряд украинских праворадикальных группировок. Так, по состоянию на начало 2017 г. из 57 запрещенных решением суда экстремистских организаций 23 имеют отношение к русскому национализму. Характерно, что в списке 2017 г. отдельную категорию представляют попавшие в список еще в феврале 2014 г. пять украинских националистических группировок: «Правый сектор», «Украинская национальная ассамблея - Украинская национальная самооборона» (УНА-УНСО), «Украинская повстанческая армия» (УПА), «Тризуб им. Степана Бандеры», «Братство» (см.: [Перечень... 2017]).

Сегодня сами русские националисты признают: «русское движение» «под гнетом собственных ошибок и противоречий, а также в условиях жестокой зачистки со стороны спецслужб... впало в глубокий кризис и ушло... в политическую тень» [Севастьянов 2016: 14].

Либерально настроенные исследователи, возлагавшие в начале 2010-х годов надежды на так называемый «демократический поворот» в русском национализме, сегодня также фиксируют кризис «русского движения», отмечая, что «в России наблюдается один из самых низких за все постсоветские годы уровень проявления не только гражданской, но и этнической солидарности русских националистов» [Паин, Федюнин 2017: 183]. Однако причины кризиса им видятся в другом: «После присоединения Крыма к России, пишет Э. Паин, - оказалось, что преодолеть имперские стереотипы не удалось даже национал-демократической элите русских националистов <...> В результате такого идейного растворения в общем потоке агрессивного патриотизма русский национализм потерял идейное своеобразие, свой особый предмет политической активности и по этой причине утратил идейную основу для консолидации даже былых идейных сторонников» [Паин, Федюнин 2017: $180]$.

В то же время очевидно, что российское посткоммунистическое государство все еще не ориентировано на продуцирование демократических или гражданских идентичностей. И поскольку «горизонтальные гражданские формы связи слабы, воспроизводится 
имперская ситуация параллельного и разобщенного функционирования таких общностей (этнических. - B.A.), связанных только через подчинение общему центру» [Паин, Федюнин 2017: 222]. Поэтому так называемая «государственная национальная политика» Центра в основном воплощается в попытках формирования и поддержания идентичностей, ориентированных на принцип лояльности к государству, а то и лояльности к носителям власти (институтам или лицам, ее представляющим). Д. Шопфлин называет тип такой идентичности этатистским. В свою очередь, социолог Б. Дубин, опираясь на данные исследований, отмечает, что «нынешний российский пассивный и диффузный «национализм большинства» (т.е. русских. - B.A.) в своей основе - державный (тотальный), а не этнический» [Дубин 2014: 15]. В большей мере это идентичность подданства, нежели гражданства, именно поэтому, по нашему мнению, необходимо различать этатистскую (подданническую) и гражданскую национальные идентичности. Другое дело, что идентичности подданства традиционно ассоциируются в России с этнической идентичностью доминирующей национальной группы. Отсюда часто звучащие требования к властям наделить этническое большинство дополнительными статусными преимуществами. Так, в подготовленном в начале нового века проекте закона «О русском народе» в качестве важнейшего рассматривался тезис о признании русских «единственным государствообразующим народом». Эта проблема стала предметом самой оживленной дискуссии и на последнем обсуждении проекта «Стратегии государственной национальной политики Российской Федерации на период до 2025 года» на уровне представителей правительств всех регионов России в Москве в ноябре 2012 г.

Как отмечает внешний наблюдатель: «гражданский национализм (российской властью. - B.A.) не приветствуется, поскольку режим не поддерживает вовлеченность своих граждан в публичную сферу; этнический национализм рассматривается как угроза единству и стабильности России; государственный (консервативный) национализм, продвигаемый режимом в качестве третьего решения, все в меньшей и меньшей степени соответствует ситуации и не способен привести к консенсусу между государством и 
гражданами» [Ларюэль 2014: 68].

Правда, как резонно утверждают социологи, «...государственная идентификация (“россиянин”, “гражданин России”) в каком-то смысле есть инобытие русской этнической: русским легче всего дается совмещение государственной (подданической. - B.A.) и этнической идентичности. Среди русских таких 73 \%, среди других национальностей России - 55 \%» [Данилова 2005: 155]. Легкость совмещения государственной и этнической идентичностей именно для русских объясняется тем, что они составляют этническое большинство страны, ощущают себя ее становым хребтом и чувствуют ответственность за все ее пространство [Соловей, Соловей 2011: 439-440]. Российский историк С. Сергеев отмечает, что у русских патриотов наблюдается «серьезная проблема со зрением: они не различают в России народ и государство, а между тем последнее в русской истории являлось в иные эпохи гораздо более злостным мучителем первого, чем любой иноземный захватчик» [Сергеев 2017: 25].

Поэтому самоидентификация русских как «граждан России» означает прежде всего формальную связь с государством и идентификацию с территорией, а не с политическим сообществом - другими такими же гражданами. Иными словами, называя себя «гражданином России», человек признает, что живет в этой стране и является подданным Кремля, но он вовсе не подразумевает свою принадлежность к политической нации «россиян» - общности, имеющей интегрирующие ценности, интересы и символы. Все это блистательно отсутствует ${ }^{9}$. Поэтому, как представляется, у этниче-

9 Согласно данным социологического исследования, проведенного Институтом социологии РАН, респонденты, отвечая на вопрос «Каких качеств сегодня недостает людям Вашей национальности?» чаще всего выбирали варианты ответов: «уважение друг к другу» $(58 \%-$ у русских и $39 \%$ - у других россиян); «взаимопомощь» (41 и $33 \%)$; честность» (39 и $31 \%)$. Таким образом, «наиболее востребованными ценностями оказались те, которые отражают дефицит фундаментальных норм общественного взаимодействия и гражданской межличностной солидарности. И в этом проявляется общая тенденция - сегодня русским (и всем россиянам) недостает простых и основополагающих ценностей, отражающих нормы честного общежития, взаимного уважения, культуры доверия, составляющие основы общества как такового» [Рыжова 2016: 168]. 
ского русского национализма есть политическое будущее.

\section{Литература и источники}

Беликов С. Бритоголовые. М.: Издательский центр РГГУ, 2002.

Биллиг М. Повседневное напоминание о Родине // Логос. 2007. № 1 (58). C. 34-71.

В Совете Европы отмечают рост национализма в России // BBC: Русская служба. 14.10.2013. URL: http://www.bbc.com/russian/ russia/2013/10/131014_ecri_russia_report (дата обращения: 05.12.2018).

Валдайский международный дискуссионный клуб, 19 сентября 2013. URL: http://kremlin.ru/events/president/news/19243 (дата обращения: 05.12.2018).

Володихин Д. Нацдвижение между империей и этносом // Политический журналъ. 2008. № 6-7. С. 66-67.

Данилова Е.Н. Россияне и поляки в зеркале этнических и гражданских идентификаций // Восточноевропейские исследования. 2005. № 1. C. $146-162$.

Дробижева Л.М., Аклаев А.Р., Коротеева В.В., Солдатова Г.Х. Демократизация и образы национализма в Российской Федерации 90-х годов. М.: Мысль, 1996.

Дубин Б. «Чужие» национализмы и «свои» ксенофобии вчерашних и сегодняшних россиян // Pro et Contra. 2014. № 1-2 (62). С. 6-18.

Готтлиб Г. Нации без государств // Проблемы Восточной Европы. 1995. № 43-44. C. 21-35.

Грин С. Природа неподвижности российского общества // Pro et Contra. 2011. № 1-2 (51). C. 5-19.

Гудков Л. Инерция пассивной адаптации // Pro et Contra. 2011. № 1-2 (51). С. 20-42.

Есть ли перспектива у русского национализма? Беседа с Львом Гудковым и Борисом Дубинным // Русский национализм: идеология и настроение: сб. статей / сост. А. Верховский. М.: Центр «Сова», 2006. С. 263-298.

Кловер Ч. Черный ветер, белый снег. Новый рассвет национальной идеи. М.: Фантом Пресс, 2017.

Кожевникова Г. Ультраправые тенденции в прокремлевских молодежных организациях // Русский национализм между властью и оппозицией / под ред. В. Прибыловского. М.: Центр «Панорама», 2010. С. 4-17.

Коровин B. Евразийство vs национал-демократия: кому действительно нужна Великая Россия? // Информационно-аналитический портал «Евразия». 28.10.2016. URL: http://evrazia.org/article/2404 (дата обращения: 
05.12.2018).

Кортунов С.В. Становление национальной идентичности: Какая Россия нужна миру: учеб. пос. для студентов вузов. М.: Изд. Аспект Пресс, 2009.

Кузьмин А.Г. Русский радикальный национализм в современной России: традиции и эволюция. Сыктывкар: РИО СыктГУ, 2011.

Ларюэль М. «Русский национализм» как область научных исследований // Pro et Contra. 2014. № 1-2 (62). С. 54-72.

Лебедев С.В. Альтернатива справа. Национально-патриотическое движение в России: историческая традиция, идеологические направления и перспективы. СПб.: Нестор, 1999.

Люкс Л. Евразийство и консервативная революция: соблазн антизападничества в России и в Германии // Политическая концептология. 2016. № 1 . С. $144-157$.

Малинова О.Ю. Тема империи в современных российских политических дискурсах // Наследие империй и будущее России / под ред. А.И. Миллера. М.: Новое литературное обозрение, 2008. С. 66-79.

Мигранян А. Россия в поисках идентичности. (1985-1995): [сб. ст. и очерков]. М.: Междунар. отношения, 1997.

Мукомель В.И. Мигрантофобии и этнофобии в современной России // Этнодиалоги: Альманах. Приложение к журналу «Этносфера». 2005. № 2 (23). С. 61-71.

Назарбаев Н.А. Проект «О формировании Евразийского союза государств» (3 июня 1994 г.) // Стратегия независимости. Алматы: Атамура, 2004. C. $110-122$.

Нас снесет потоком? Чем опасны для народа миграционные планы властей // Аргументы и факты. 02.05.2012. № 18. С. 7.

Нужен ли Гитлер России? По материалам международного форума «Фашизм в тоталитарном и посттоталитарном обществе: идейные основы, социальная база, политическая активность», Москва, 20-22 янв. 1995 / сост. и авт. вступит. ст. В. Илюшенко. М.: ПИК, 1996.

Паин Э. Распутица: полемические размышления о предопределенности пути России. М.: РОССПЭН, 2009.

Паин Э., Федюнин С. Нация и демократия: перспективы управления культурным разнообразием. М.: Мысль, 2017.

ПАСЕ призвала Россию остановить национализм // Лента.ru. 05.04.2006. URL: http://lenta.ru/news/2006/04/05/pace/ (дата обращения: 05.12.2018).

Перечень некоммерческих организаций, в отношении которых судом 
принято вступившее в законную силу решение о ликвидации или запрете деятельности по основаниям, предусмотренным ФЗ «О противодействии экстремистской деятельности». URL: http://minjust.ru/ru/nko/perechen_ zapret (дата обращения: 05.05.2017).

Прибыловский В. Тоталитаризм, коммунисты, национал-патриоты и фашисты. Термины и реальность. // Нужен ли Гитлер России?: По материалам междунар. форума «Фашизм в тоталитар. и посттоталитар. о-ве: идейн. основы, соц. база, полит. активность», Москва, 20-22 янв. 1995 г. / сост. и авт. вступит. ст. В. Илюшенко. М.: ПИК, 1996. С. 13-19.

Программа партии «Российский Общенародный Союз». URL: http:// partiya-ros.ru/docs/programma.html (дата обращения: 11.05.2012).

Путин B.В. Новый интеграционный проект для Евразии - будущее, которое рождается сегодня // Известия. 03.10.2011.

Рыжова С.В. О ценностных характеристиках современной русской этнической идентичности // Власть. 2016. № 9. С. 163-172.

Салмин А.М. Миф истории и история мифа // Национальная идея: страны, народы и социумы / отв. ред. Ю.С. Оганисьян. М.: Наука, 2007. C. 3-13.

Севастьянов А.Н. Русское движение за тридцать лет (1985-2015). Заметки очевидца. М.: Самотека; МИД «Осознание», 2016.

Сергеев С. «Руссизм»: третья волна // Политический класс. 2008. № 6. C. 64-68.

Сергеев С.M. Русская нация, или Рассказ об истории ее отсутствия. М.: Центрполиграф, 2017.

Советский простой человек. Опыт социального портрета на рубеже 90-х годов. М.: Мировой океан, 1993.

Соловей T., Соловей В. Несостоявшаяся революция: исторические смыслы русского национализма. М.: АСТ; Астрель, 2011.

Соловей T., Соловей В. Русский национализм при Путине-Медведеве // Русский национализм между властью и оппозицией / под ред. В. Прибыловского. М.: Центр «Панорама», 2010. С. 51-62.

Филиппов B.P. Кризис этнического федерализма в России // Регионы и регионализм в странах Запада и России. М.: Институт всеобщей истории РАН, 2001. С. 182-189.

Умланд А. Правый экстремизм в постсоветской России // Общественные науки и современность. 2001. № 4. С. 71-84;

Умланд А. Три разновидности постсоветского фашизма // Русский национализм: идеология и настроения: сб. статей. М.: Центр «Сова», 2006. 
C. 221-262.

Энтин М., Энтина Е. Всеобъемлющее Большое Евразийское партнерство: уход от реальности или возвращение к ней // Вся Европа. 2016. № 11 (115). URL: http://alleuropalux.org/?p=13969 (дата обращения: 05.12.2018).

Янов А.Я. После Ельцина. «Веймарская» Россия. М.: КРУК, 1995.

Laruelle M. Russian Eurasianasm: An Ideology of Empire. Washington; Baltimor: The Johns Hopkins University Press, 2008. 


\title{
POWER AND RUSSIAN NATIONALISM IN CONTEMPORARY RUSSIA
}

\section{Achkasov}

\begin{abstract}
The paper notes the complexity and inconsistency of relations between the Russian authorities and Russian nationalism. In the early 1990s, many observers predicted a strengthening of the political role of Russian ethnic nationalism. Such predictions were made after the unexpected electoral success of the party of V.V. Zhirinovsky in December 1993. However, this predictions was not confirmed at that time. In the new century, imperial-great-power and ethnonationalist ideas and forces occupied the dominant position within the framework of Russian nationalism. After the choice made by the Russian authorities in favor of the Eurasian integration project, it was assumed that Russian nationalism could offer the Eurasian "civilizational" identity and traditional anti-Westernism as a basis for cooperation. Over the years, work has been done on recruiting, co-opting and "taming" the leaders of nationalist organizations (official positions for some of the leaders of this camp, selective access to state-owned media, financial support for some nationalist Internet sites, etc.). However, in their desire to "tame" ethnic Russian nationalism, the authorities faced serious obstacles. Therefore, in 2010-2011 s. Russian authorities began to struggle with radical nationalist groups. However, since state identification ("Russian", "citizen of Russia") is in some sense a different being of Russian ethnic identity. It means that ethnic Russian nationalism has a political future.
\end{abstract}

Keywords: imperial and ethnic Russian nationalism, ethnic identity, Russian authorities, Eurasian idea, civilizational identity.

\section{References}

Belikov S. Britogolovye [Skinheads]. Moscow: Publishing Center of the RSHU, 2002. (In Russian)

Billig M. Povsednevnoe napominanie o Rodine [Everyday Reminder about 
Homeland], Logos, 2007, 1 (58), pp. 34-71. (In Russian)

Clover H. Chernyj veter, belyj sneg. Novyj rassvet nacional'noj idei [Black wind, white snow. New dawn of the national idea]. Moscow: Phantom Press, 2017. (In Russian)

Danilova E.N. Rossijane i poljaki v zerkale jetnicheskih i grazhdanskih identifikacij [Russians and Poles in the mirror of ethnic and civil identities], Vostochnoevropejskie issledovanija [Eastern European Studies], 2005, 1, pp. 146162. (In Russian)

Drobizheva L.M., Aklaev A.R., Koroteeva V.V., Soldatova G.Kh. Demokratizacija $i$ obrazy nacionalizma $v$ Rossijskoj Federacii 90-h godov [Democratization and images of nationalism in the Russian Federation of the 1990s]. Moscow: Mysl', 1996. (In Russian)

Dubin B. «Chuzhie» nacionalizmy i «svoi» ksenofobii vcherashnih i segodnjashnih rossijan ["Aliens" nationalism and "their" xenophobia of yesterday's and today's Russians], Pro et Contra, 2014, 1-2 (62), pp. 6-18. (In Russian)

Entin M., Entina E. Vseob\#emljushhee Bol'shoe Evrazijskoe partnerstvo: uhod ot real'nosti ili vozvrashhenie $k$ nej [Comprehensive Large Eurasian Partnership: withdrawing from reality or returning to it, Vsja Evropa [Whole Europe], 2016, no. 11 (115). URL: http://alleuropalux.org/?p=13969 (available: 05.12.2018). (In Russian)

Est' li perspektiva u russkogo nacionalizma? Beseda s L'vom Gudkovym i Borisom Dubinnym [Is there a future of Russian nationalism? Conversation with Lev Gudkov and Boris Dubinny]. In: Russkij nacionalizm: ideologija $i$ nastroenie: sb. statej [Russian nationalism: ideology and mood]. Comp. A. Verkhovsky. Moscow: Center "Sova”, 2006, pp. 263-298. (In Russian)

Filippov V.R. Krizis jetnicheskogo federalizma v Rossii [The crisis of ethnic federalism in Russia]. In: Regiony $i$ regionalizm $v$ stranah Zapada $i$ Rossii [Regions and regionalism in the countries of the West and Russia]. Moscow: Institute of General History, Russian Academy of Sciences, 2001, pp. 182-189. (In Russian)

Gottlieb G. Nacii bez gosudarstv [Nations without States], Problems of Eastern Europe [Problems of Eastern Europe]. 1995, 43-44, pp. 21-35. (In Russian)

Green S. Priroda nepodvizhnosti rossijskogo obshhestva [The nature of the immobility of Russian society ], Pro et Contra, 2011, 1-2 (51), pp. 5-19. (In Russian)

Gudkov L. Inercija passivnoj adaptacii [Inertia of passive adaptation], Pro 
et Contra, 2011, 1-2 (51), pp. 20-42. (In Russian)

Korovin V. Evrazijstvo vs nacional-demokratija: komu dejstvitel'no nuzhna Velikaja Rossija? [Eurasianism vs National Democracy: who really needs Great Russia], Informacionno-analiticheskij portal «Evrazija» [Information and analytical portal «Eurasia»], 28.10.2016. URL: http://evrazia.org/article/2404 (available: 05.12.2018). (In Russian)

Kortunov S. Stanovlenie nacional'noj identichnosti: Kakaja Rossija nuzhna miru: Uchebnoe posobie dlja studentov vuzov [The development of national identity: What kind of Russia does the world need? A study guide for university students]. Moscow: Aspect Press, 2009. (In Russian)

Kozhevnikova G. Ul'trapravye tendencii v prokremlevskih molodezhnyh organizacijah [Ultra-Right Trends in Pro-Kremlin Youth Organizations]. In: Russkij nacionalizm mezhdu vlast'ju i oppoziciej [Russian nationalism between the government and the opposition]. Ed. V. Pribylovsky. Moscow: Center «Panorama», 2010, pp. 4-17. (In Russian)

Kuzmin A.G. Russkij radikal'nyj nacionalizm v sovremennoj Rossii: tradicii $i$ jevoljucija [Russian radical nationalism in modern Russia: traditions and evolution]. Syktyvkar: Syktyvkar State University, 2011. (In Russian)

Laruelle M. Russian Eurasianasm: An Ideology of Impire. Washington; Baltimor: The Johns Hopkins University Press 2008.

Laruelle M. «Russkij nacionalizm» kak oblast' nauchnyh issledovanij [«Russian nationalism» as a field of research], Pro et Contra, 2014, 1-2 (62), pp. 54-72. (In Russian)

Lebedev S.V. Al'ternativa sprava. Nacional'no-patrioticheskoe dvizhenie $v$ Rossii: istoricheskaja tradicija, ideologicheskie napravlenija $i$ perspektivy [Alternative to the right. The national-patriotic movement in Russia: historical tradition, ideological trends and prospects]. St. Petersburg: Nestor, 1999. (In Russian)

Lux L. Evrazijstvo i konservativnaja revoljucija: soblazn antizapadnichestva v Rossii i v Germanii [Eurasianism and the Conservative Revolution: The Temptation of Anti-Westernization in Russia and Germany], Political Conceptology, 2016, 1, pp. 144-157. (In Russian)

Malinova O. Yu. Tema imperii v sovremennyh rossijskih politicheskih diskursah [The theme of the empire in modern Russian political discourses]. In: Nasledie imperij $i$ budushhee Rossii [The legacy of empires and the future of Russia]. Ed. by A.I. Miller. Moscow: New literary observer 2008, pp. 66-79. (In Russian)

Migranyan A. Rossija v poiskah identichnosti. (1985-1995) [Russia in search 
of identity. (1985-1995)] Moscow: Intern. relationship, 1997. (In Russian)

Mukomel V.I. Migrantofobii i jetnofobii v sovremennoj Rossii [Migrantphobia and ethnophobia in modern Russia], Ethno-dialogues: Almanac. Supplement to the journal «Ethnosfera». 2005, 2 (23), pp. 61-71. (In Russian)

Nas snesjot potokom? Chem opasny dlja naroda migracionnye plany vlastej [Will we be blown away? What is dangerous for the people of the migration plans of the authorities], Argumenty i fakty, 02.05.2012, pp. 7. (In Russian)

Nazarbayev N.A. Proekt «O formirovanii Evrazijskogo sojuza gosudarstv» (3 ijunja 1994 g.) [The project "On the formation of the Eurasian Union of States» (June 3, 1994)]. In: Strategy of independence. Almaty: Atamura, 2004, pp. 110-122. (In Russian)

Nuzhen li Gitler Rossii? Po materialam mezhdunarodnogo foruma «Fashizm $v$ totalitarnom i posttotalitarnom obshhestve: idejnye osnovy, social'naja baza, politicheskaja aktivnost'» [Does Russia need Hitler? On the materials of the international forum "Fascism in a Totalitarian and Post-Totalitarian Society: Ideological Foundations, Social Base, Political Activity"], Moscow, January 2022. 1995: Collection. Comp. and auth. entry Art. V. Ilyushenko. Moscow: PIK, 1996. (In Russian)

Pain E. Rasputica: Polemicheskie razmyshlenija o predopredelennosti puti Rossii [Slush: Polemic reflections on the predetermination of the path of Russia]. Moscow: ROSSPEN, 2009. (In Russian)

Pain E., Fedyunin S. Nacija i demokratija: perspektivy upravlenija kul'turnym raznoobraziem [Nation and democracy: perspectives of managing cultural diversity]. Moscow: Mysl', 2017. (In Russian)

PASE prizvala Rossiju ostanovit' nacionalizm [PACE urged Russia to stop nationalism], Lenta.ru, 5/04/2006. URL. http://lenta.ru/news/2006/04/05/pace/ (available: 05.12.2018). (In Russian)

Perechen' nekommercheskih organizacij, votnoshenii kotoryh sudom prinjato vstupivshee $v$ zakonnuju silu reshenie o likvidacii ili zaprete dejatel'nosti po osnovanijam, predusmotrennym $F Z$ «O protivodejstvii jekstremistskoj dejatel'nosti» [The list of non-profit organizations in respect of which the court made the decision on the liquidation or prohibition of activities entered into force on the grounds provided for by the Federal Law "On Countering Extremist Activities»]. URL: http://minjust.ru/ru/nko/perechen_zapret (available: 05.05.2017). (In Russian)

Pribylovsky V.Totalitarizm, kommunisty, nacional-patrioty i fashisty. Terminy i real'nost' [Totalitarianism, communists, national patriots and fascists. Terms and reality]. In: Nuzhen li Gitler Rossii?: Po materialam mezhdunar. 
foruma «Fashizm v totalitar. i posttotalitar. o-ve: idejn. osnovy, soc. baza, polit. aktivnost'» [Does Russia need Russia? On the materials of the international forum "Fascism in totalitarian. and post-totalitarian society: ideological. foundations, social base, political. activity"]. Moscow, 20-22 Jan. 1995. Comp. and auth. entry Art. V. Ilyushenko]. Moscow: PIK, 1996, pp. 13-19. (In Russian)

Programma partii «Rossijskij Obshhenarodnyj Sojuz» [The program of the party «Russian Union of All People»]. URL: http://partiya-ros.ru/docs/ programma.html (available: 11.05.2012). (In Russian)

Putin V.V. Novyj integracionnyj proekt dlja Evrazii — budushhee, kotoroe rozhdaetsja segodnja [New integration project for Eurasia - the future that is born today], Izvestia, 03.10.2011. (In Russian)

Ryzhova S.V. O cennostnyh harakteristikah sovremennoj russkoj jetnicheskoj identichnosti [On the value characteristics of modern Russian ethnic identity], Vlast' [Power], 2016, 9, pp. 163-172.

Salmin A.M. Mif istorii i istorija mifa [The myth of history and the history of myth]. In: Nacional'naja ideja: strany, narody i sociumy [National idea: countries, peoples and societies]. Ed. ed. Yu.S.Oganisyan. Moscow: Nauka, 2007, pp. 3-13. (In Russian)

Sevastyanov A.N. Russkoe dvizhenie za tridcat' let (1985-2015). Zametki ochevidca [Russian movement for thirty years (1985-2015). Eyewitness notes]. Moscow: Samotech; MFA “Awareness", 2016. (In Russian)

Sergeev S. «Russizm»: tret'ja volna ["Russism": the third wave], Political class [Political class], 2008, 6, pp. 64-68. (In Russian)

Sergeev S. Russkaja nacija, ili Rasskaz ob istorii ee otsutstvija [The Russian Nation, or the Story about Its Absence]. Moscow: Tsentrpoligraf, 2017. (In Russian)

Sovetskij prostoj chelovek». Opyt social'nogo portreta na rubezhe 90-h godov [The Soviet simple man «. The experience of a social portrait at the turn of the 90s]. Moscow: Mirovoj okean, 1993. (In Russian)

Solovey T., Solovey V. Nesostojavshajasja revoljucija: Istoricheskie smysly russkogo nacionalizm [The Frustrated Revolution: Historical Meanings of Russian Nationalism]. Moscow: AST: Astrel, 2011. (In Russian)

Solovey T., Solovey V. Russkij nacionalizm pri Putine-Medvedeve [Russian nationalism under Putin-Medvedev]. In: Russkij nacionalizm mezhdu vlast'ju i oppoziciej [Russian nationalism between the government and the opposition]. Ed. by V. Pribylovsky. Moscow: Center «Panorama», 2010, pp. 51-62. (In Russian)

Umland A. Pravyj jekstremizm v postsovetskoj Rossii [Right-Wing Extremism in Post-Soviet Russia], Obshhestvennye nauki i sovremennost' [Social 
Sciences and Modernity], 2001, 4, pp. 71-84. (In Russian)

Umland A. Tri raznovidnosti postsovetskogo fashizma [Three Variants of Post-Soviet Fascism]. In: Russkij nacionalizm: ideologija i nastroenija [Russian Nationalism: Ideology and Moods]. Collection of Articles. Moscow: Center "Sova", 2006, pp. 221-262. (In Russian)

V Sovete Evropy otmechajut rost nacionalizma v Rossii [The European Council noticed the rise of nationalism in Russia], BBC: Russian Service, 10/14/2013. URL: http://www.bbc.com/russian/russia/2013/10/131014_ecri_ russia_report (available: 05.12.2018). (In Russian)

Valdajskij mezhdunarodnyj diskussionnyj klub [Valdai International Discussion Club], September 19, 2013. URL: http://kremlin.ru/events/president/ news/19243 (available: 05.12.2018). (In Russian)

Volodikhin D. Nacdvizhenie mezhdu imperiej i jetnosom [National Movement Between Empire and Ethnic Group], Politicheskij zhurnal [Political Journal], 2008, 6-7, pp. 66-69. (In Russian)

Yanov A. Posle El'cina. "Vejmarskaja» Rossija [After Yeltsin. "Weimar" Russia]. Moscow: KRUK, 1995. (In Russian) 